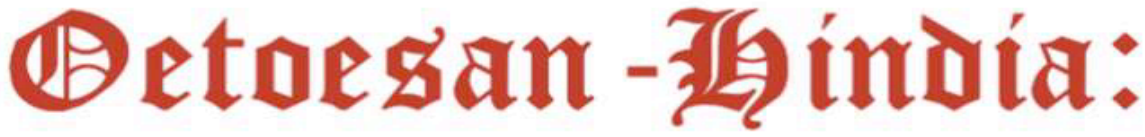

Telaah Pemikiran Kebangsaan

Volume 2 No 2 Tahun 2020 Hlmn. 76-83

Artikel Masuk 11 Agustus 2020 I Artikel Diterima 2 Desember 2020

\section{Novel corona virus diseases 2019 dan dampak yang timbul pada keluarga}

\section{Myllani Tsesar Caturjuniandri}

Yayasan Peneleh Jang Oetama, Pondok Indah Estate Blok B No 11A, Malang, Indonesia, 65124

myllanij@gmail.com

\begin{abstract}
Abstrak
Penelitian ini bertujuan untuk menjelaskan bahwa covid-19 cukup berdampak pada psikologis individu dalam hal perubahan emosi, serta rasa cemas, dan takut. Metode yang digunakan ialah berjenis naratif kualitatif. Tak hanya memengaruhi psikologi, pandemi ini juga mengubah cara individu dalam menjalin hubungan sosial dengan masyarakat dengan pemaksimalan penggunaan sosial media sesuai dengan peraturan pemerintah terkait pencegahan pandemi. Aktivitas sehari-hari pun mengalami perubahan yang cukup berbeda akibat adanya peraturan pencegahan covid. Namun pada kenyataan masih banyak warga yang kurang patuh terhadap protokol kesehatan.
\end{abstract}

Kata Kunci: virus; psikologi keluarga; aktivitas

\begin{abstract}
This study aims to explain that Covid-19 has quite an impact on individual psychology in terms of emotional changes, anxiety, and fear. The method used is a qualitative narrative type. Covid-19 does not only affect psychologically, but also changes the way individuals establish social relations with the community by maximizing the use of social media in accordance with government regulations related to pandemic prevention. Daily activities are also transformed due to the existence of covid prevention regulations. However, in reality there are still many people who do not comply with health protocols.
\end{abstract}

Keywords: virus; family psychology; activities

Novel Corona Virus Diseases 2019 atau yang biasa kita kenal dengan sebutan covid-19 merupakan sebuah pandemi yang berasal dari Wuhan, China. Diketahui virus ini serumpun dengan Severe Acute Respiratory Syndrome (SARS) yang menyerang sistem pernapasan manusia dan merusak imunitas tubuh. Dilansir dari worldometer.info, terc sebanyak 20,319 juta orang telah terinfeksi oleh virus tersebut dengan total kematian sebesar 74.352 dan 13,242 juta orang telah sembuh. Pandemi ini tak hanya menyerang negara tersebut melainkan hampir seluruh negara di dunia termasuk Indonesia. Pada tanggal 11 Agustus 2020 dikutip dari laman tersebut, 
Indonesia mencatat sebanyak 128.776 jiwa positif covid dengan peningkatan kasus positif sebanyak 1.693 orang dalam satu hari. Angka positif ini semakin hari semakin mengalami peningkatan dan membuat pemerintah sigap dengan menyusun segala skenario yang diperlukan bagi kehidupan warganya mulai dari sektor perekonomian hingga sektor pendidikan sekalipun. Kala itu diberlakukan Work From Home (WFH) bagi pekerja, Learn From Home (LFM) atau Study From Home (SFH) bagi pelajar, dan Pembatasan Sosial Berskala Besar (PSBB) serta protokol pencegahan covid lainnya.

Terhitung sejak maret, terdapat banyak pro dan kontra terhadap kebijakan pemerintah. Tak sedikit pula warga yang kurang memahami betapa bahayanya virus ini. Penolakan demi penolakan terjadi dimana-mana termasuk penolakan pemakaman jenazah sesuai protokol pencegahan covid oleh keluarga jenazah, kemudian juga warga di salah satu desa yang menolak pemakaman jenazah dengan riwayat positif covid-19, padahal lokasi pemakaman masih terbilang ada jarak aman dari lingkungan warga dan penerapan protokol yang sudah diperketat. Masih banyak kasus penolakan lainnya. Hal ini terjadi akibat pemahaman yang kurang mendalam dan terkendala oleh berbagai macam faktor. Terlebih warga Indonesia lebih takut akan sanksi sosial dan adat istiadat daripada sanksi lain.

Pemerintah bersama relawan dan semua lapisan masyarakat yang cukup berpengaruh pun ikut mengedukasi warga sekitar dengan berbagai cara baik melalui siaran televisi, penyebaran di media sosial, hingga sosialisasi secara langsung. Terlebih saat ini pemerintah sedang mematangkan skenario new normal life atau tatanan hidup baru menjadi pr lebih bagi seluruh warga untuk memahami peraturan pencegahan covid dalam new normal life. Tiga bulan lamanya masyarakat mulai beradaptasi dengan kondisi saat ini dan tak dapat dipungkiri bahwa adaptasi ini akan selalu menimbulkan dampak terlepas dari apakah dampak tersebut merupakan dampak yang positif maupun negatif. Penelitian ini hadir dengan tujuan untuk mengungkapkan dampak apa saja yang ditimbulkan dalam sebuah keluarga akibat adanya pandemi ini. Diharapkan dengan adanya penelitian ini, akan terkuak apa yang sebenarnya terjadi dan dampak seperti apa yang muncul khususnya dalam sebuah keluarga

\section{Metode}

Metode yang digunakan dalam penulisan ini adalah metode naratif kualilatif. Pengambilan data penelitian dilakukan secara langsung dengan mewawancari satu keluarga dengan tiga orang sebagai narasumber yaitu kepala keluarga, ibu rumah tangga, dan anak. Penelitian dilakukan pada bulan Juni 2020. Informan penelitian ini adalah seorang pegawai pensiun (SY), ibu rumah tangga (VP), dan seorang remaja (MT) dalam satu keluarga. Keluarga yang dipilih berlokasi di Tulungagung, Jawa Timur. Wawancara terkait pemahaman tentang covid 19, termasuk cara penyebaran hingga pemikiran mereka tentang penderita covid-19 juga dieksplorasi. 
Hasil dan Pembahasan

Adanya pandemi covid-19 jelas memberikan dampak psikososial bagi seluruh keluarga di Indonesia. Dampak ini meliputi perilaku mematuhi protokol kesehatan, psikologis, aktivitas sosial, keimaman, serta komunikasi. Berdasarkan hasil penelitian yang telah dilakukan, kepada salah satu keluarga di Tulungagung, semua informan memiliki pengalaman yang berbeda-beda dengan covid-19 ini.

\section{SY (Ayah/ Suami)}

Informan yang pertama, adalah SY, yang merupakan seorang pegawai BUMN namun telah pensiun sekitar satu bulan yang lalu. SY serta istri (VP) dan anaknya tinggal di Lombok sejak dua tahun lalu. Kemudian kembali lagi ke kampung halaman mereka di Tulungagung setelah SY pensiun. Mereka berpindah sekitar bulan April di saat pandemi covid-19 telah melanda Indonesia. Sebelum pindah dari Lombok ke Tulungagung, informan menceritakan harus melalui tes kesehatan terlebih dahulu. Jika telah dilakukan, informan baru boleh melakukan perjalanan dengan senantiasa memperhatikan protokol kesehatan yang telah diterapkan. Mereka juga menyiapkan desinfektan, membawa hand sanitizer juga membawa bekal sendiri guna untuk meminimalisir kemungkinan tertularnya virus ini.

Informan menceritakan ketika telah sampai di Tulungagung, mereka langsung melapor kepada ketua RT tempat mereka tinggal, dan dinyatakan sebagai ODP. Seperti yang diketahui, setiap ODP harus melakukan isolasi mandiri selama empat belas hari. Informan sekeluarga pun juga melakukan hal yang sama. Selama dua minggu mereka tidak pergi ke luar rumah sama sekali. Untuk memenuhi kebutuhan sehari-hari, informan mengungkapkan bahwa mereka dibantu oleh adik mereka, juga kerja sama dengan warga sekitar.

Ketika ditanyai tentang kondisi fisik saat pandemi, informan SY mengatakan bahwa tidak terjadi banyak perubahan, rasanya biasa saja. Namun untuk aktivitas fisik, informan SY mengungkapkan terjadinya pembatasan. Apalagi ditambah status mereka sebagai ODP. Informan SY juga mengungkapkan bahwa senantiasa untuk memenuhi segala protokol kesehatan yang berlaku. Informan juga sadar untuk mengurangi kegiatan berkumpul, senantiasa memakai masker, ketika berpergian harus melihat situasi dan kondisi serta mempersiapkan semuanya untuk segala situasi. Mengenai perasaannya tentang pandemi ini, informan SY mengungkapkan:

“...tidak [perlu] menciptakan rasa takut namun kita harus mengetahui bagaimana cara penularan virus karena hal tersebut adalah yang terpenting...dan tetap harus waspada"

Ketika ditanyai tentang apakah mempunyai rasa takut terhadap virus ini, informan mengatakan bahwa harus tetap waspada pada setiap keadaan. Mengenai kondisi saat pandemi pun informan mengatakan harus tetap sabar mengadapi, dan mencari jalan keluar ketika ada masalah. Untuk rutinitas ibadah, informan mengungkapkan tidak ada perubahan yang signifikan. Informan tetap pergi ke masjid, 
namun dengan tetap mengedepankan protokol kesehatan serta kebersihan.

Informan SY juga merupakan seseorang yang cukup aktif menggunakan media sosial sebagai sarana untuk mencari informasi terbaru mengenai pandemi. Namun, informasi yang diterima adalah informasi yang sudah jelas kebenarannya dan bukan sekedar kabar burung belaka. Tidak terjadi perubahan yang berarti dalam relasi antara anggota keluarga. Informan justru mengatakan bahwa menyenangkan untuk bisa menghabiskan waktu bersama dengan keluarga. Untuk masalah dengan rekan kerja yang tidak bisa pulang, informan tetap bertegur sapa melalui media sosial untuk saling bertukar informasi terbaru.

Pendapat informan SY mengenai orang yang terpapar covid-19 adalah untuk tidak terlalu panik, harus menjalani, pasrah: “...intinya adalah dijalani saja dengan sesuai protokol kesehatan". Informan SY juga mengetahui beberapa cara yang diperlukan sebagai upaya untuk memutus mata rantai penyebaran virus ini. Informan juga mengetahui gejala munculnya covid-19.

\section{2. $\quad \mathrm{VP}(\mathrm{Ibu} /$ Istri)}

Informan yang kedua adalah istri dari SY, yaitu ibu VP. Beliau adalah seorang ibu rumah tangga. Beliau dinyatakan sebagai ODP karena memiliki riwayat dari Lombok. Informan VP menjalani masa karantina mandiri selama kurun waktu dua minggu atau empat belas hari. Hal ini tentu saja memberikan dampak yang cukup signifikan mengenai kehidupan sosial informan VP. Selama masa karantina mandiri berlangsung, VP dibantu oleh keluarga dan juga warga sekitar.

Selama karantina mandiri, informan VP mengatakan bahwa merasa cukup stres. Diketahui VP merupakan orang yang senang bersosialisasi sehingga ketika menjalani masa karantina tersebut beliau merasa kurang nyaman. Beliau juga mengungkapkan bahwa tidak terbiasa untuk di rumah saja. Namun, informan VP memilih untuk “...enjoy serta menikmati masa karantina ini”.

Beliau mengisi waktu dengan bersih-bersih rumah yang telah lama tidak ditempati serta menonton youtube untuk mencari resep masakan baru. Mengenai reaksi fisik, informan VP juga tidak mengalami reaksi fisik yang berlebih. Hanya saja merasakan keanehan ketika selama dua minggu tidak bertemu dengan manusia lain selain orang rumah. Dalam aktivitas fisik pun, beliau mengungkapkan tidak terjadi perubahan khusus. Beliau menghabiskan waktu dengan bersantai dengan keluarga serta melakukan diskusi ringan ketika sedang menonton tv bersama-sama.

Mengenai perasaan informan VP, beliau mengungkapkan “... merasa kacau karena tidak bisa berinteraksi langsung dengan orang lain”. Namun, karena dukungan yang diberikan orang-orang dan lingkungan tempat tinggal informan, informan merasa bangga kepada mereka. Informan VP juga memiliki cara tersendiri untuk mengelola emosi, yaitu dengan rutin beribadah dan tetap berkomunikasi dengan orang lain melalui media online, ataupun sekedar bertegur sapa dengan warga yang tak sengaja melewati rumah mereka. 


\section{Novel corona virus... \\ Caturjuniandri, M.T.}

Informan VP juga menggunakan media sosial untuk mencari tahu informasi terkini tentang pandemi. Interaksi dengan keluarga pun tetap norman dan seperti biasa (tidak ada perubahan). Mengenai hubungannya dengan suami, beliau mengatakan tidak banyak berubah, tetap bercanda tawa seperti biasa. Mengenai orang yang terpapar covid-19, beliau kurang memberikan simpati, namun tetap memberikan pendapat untuk tidak melakukan diskriminasi. Upaya yang dilakukan untuk mengatasi pandemi di lingkungan tempat tinggal informan adalah biasa saja. Karena informan tidak keluar selama empat belas hari, beliau juga tidak banyak tahu. Namun, perlu diapresiasi bahwa lingkungan RT di sekitar tempat tinggal informan termasuk sadar atas keberadaan covid-19 ini.

Dalam pemahaman tentang pandemi ini, informan mengatakan bahwa yang paling rentan untuk terpapar virus ini adalah anak-anak. Beliau mengungkapkan bahwa anak-anak biasanya tidak mengetahui habis bermain apa atau memegang apa dan kemudian beralih memegang daerah wajah tanpa mencuci tangan terlebih dahulu. Beliau juga berpendapat bahwa virus yang mungkin terbawa oleh anak-anak akan menyebar ke orang tua atau orang yang berada di rumah. Beliau juga mengetahui gejala umum tentang covid-19 yaitu demam, panas, batuk, sakit tenggorokan, dan lainlain. Untuk upaya pencegahan, informan VP menyarankan untuk mengikuti mengikuti protokol dari pemerintah, menghindari berkumpul, pakai masker, menyiapkan hand sanitizer dan desinfektan, rajin mencuci tangan, dan menjaga pola hidup bersih.

\section{MT (Anak Pertama)}

Informan yang ketiga dalam penelitian ini adalah MT, seorang mahasiswi di salah satu kampus swasta di Malang. Ketika kampus mengumumkan untuk belajar daring selama sisa semester, informan memilih untuk pulang kampung ke Tulungagung. Pada reaksi fisik, informan mengatakan tidak terjadi perubahan khusus. Namun, untuk aktivitas fisik, informan mengatakan cukup mengalami kesulitan karena biasanya informan adalah orang yang selalu bertemu dengan orang banyak dan ketika harus berdiam diri di rumah, dia merasakan sesuatu yang berbeda. Pada awal-awal pandemi, informan mengatakan mengalami stres selama beberapa hari karena belum terbiasa. Namun sekarang, sudah cukup terbiasa dan mencoba untuk menikmati hidup.

Perihal masalah spiritual, informan mengatakan untuk "manut" terhadap apa yang telah digariskan Tuhan. Selama masa pandemi pun, informan MT tetap melakukan ajaran agama sesuai dengan kepercayaannya. Untuk update mengenai informasi terbaru, informan juga mengandalkan media sosial untuk membantunya. Pada relasi antara keluarga tidak ada perubahan khusus. Berbeda dengan interaksi dengan pasangan, di mana informan harus menjalankan LDR dikarenakan terpisah oleh jarak sehingga hanya mengandalkan chat dan telpon saja. Begitupun dengan orang lain dan relasi, informan juga melakukan hal sama. Menurut informan intinya adalah untuk tetap menjalin komunikasi. Pendapat informan mengenai orang yang terpapar covid-19 adalah: 


\section{Oetoesan Hindia: Telaah Pemikiran Kebangsaan Volume 2 No 2 Tahun $2020 \mathrm{Hlmn}$. 76-83}

"Semoga mereka cepat sembuh, tidak ada salahnya terpapar virus, yang
salah ialah membohongi orang sekitar dan tidak menjaga kebersihan serta
imun."

Pendapat mengenai pemerintah setempat yang menangani virus ini adalah belum adanya kesadaran masyarakat yang mungkin dapat menghalangi penanganan yang dilakukan oleh pemerintah. Informan juga paham mengenai apa itu pandemi covid-19, dia menyebutkan:

"covid adalah virus yang menyerang sistem pernafasan dan imun. Tingkat bahayanya akan semakin meningkat apabila individu memiliki komorbid dan atau imun yang rendah. Waspada boleh khawatir boleh yang tidak boleh adalah berlebihan."

Informan juga mengatakan bahwa gejala virus ini bisa berbeda-beda untuk setiap orangnya. Upaya yang informan lakukan dalam rangka pencegahan virus ini pun cukup beragam yaitu dengan senantiasa menggunakan masker, membawa hand sanitizer, konsumsi makanan bergizi serta vitamin $\mathrm{C}$, menjaga kebersihan, mengganti baju ketika mau keluar dan sehabis dari luar, rajin cuci tangan, dan lain sebagainya.

Gambaran dampak psikososial yang disebabkan oleh COVID-19, dijabarkan dalam bentuk tema-tema yang diperoleh dari hasil analisis karakteristik partisipan dan hasil wawancara terhadap partisipan. Dalam aspek pertama faktor perubahan emosi dari hasil wawancara didapatkan hasil bahwa dari COVID-19 ini menyebabkan gangguan perubahan emosi ditunjukkan seperti cemas dan takut. Cemas dan takut yang dialami partisipan merupakan salah satu dampak psikologis yang disebabkan karena adanya pemberitaan oleh media mengenai covid-19. Respon pikologis yang terungkap dari partisipan saat ini adalah cemas, takut dan menerima keadaan sekarang. cemas dan takut yang dialami oleh partisipan adalah tidak berani keluar sampai sampai melakukan panic buying.

Salah satu faktor ialah adanya sumber informasi yang sangat mudah diakses contoh internet, sosial media, sampai siaran televisi menyiarkan pemberitaan covid-19. Hal tersebut sangat mepengaruhi pola pikir dari masyarakat modern saat ini, seperti maraknya kasus COVID19 yang selalu menjadi topik utama dalam pembicaraan warganet. Corona Virus Disease (COVID-19) adalah jenis virus baru yang menular pada manusia dan menyerang gangguan system pernapasan sampai berujung pada kematian Thalia (dalam Zulfa, 2020). Informasi - informasi yang didapatkan asli atau palsu mengenai covid ini sangat berpengaruh pada emosional.

Dalam segi perubahan hubungan sosial kemasyarakatan, maka dalam masa pandemi ini masyarakat tidak boleh bersosialisasi dengan langsung. Masyarakat dihimbau untuk melakukan apa saja di dalam rumah. Menurut Mirdasy (dalam Mundakir, 2007), dampak disintegrasi sosial, tercerai-berainya masyarakat, dan hancurnya budaya pasca-terjadinya bencanasangatlah serius, meskipun tidak kasat 


\section{Novel corona virus... \\ Caturjuniandri, M.T.}

mata dan tidak bisa dikuantifikasi. Selain itu, rusaknya komunitas, hancurnya struktur tatanan masyarakat, tercerai-berainya jaringan formal dan informal, perkumpulan-perkumpulan,merupakan kehilangan modal sosial yang sangat mahal. Jadi masyarakat merasa terisolasi satu dengan lainnya, tuntutan ekonomi pun bisa menjadi pemicu rasa cemas itu dimana ketika masyarakat dihimbau untuk tidak keluar rumah otomatis berkurangnya pemasukkan padahal hidup ini harus jalan terus. Kecemasan dapat direduksi dengan perilaku yang positif seperti selalu mencuci tangan, menggunakan masker, memperhatikan protokol kesehatan serta akan lebih baik jika melakukan social distancing (menjaga jarak) untuk sementara waktu hingga pandemi ini mereda.

Mengenai komunikasi, keluarga ini memiliki kesadaran yang cukup baik dalam menjalin komunikasi. Setiap anggota keluarga rajin untuk menghubungi kerabat mereka walaupun hanya untuk bertukar kabar dan saling berbagi informasi. Mereka juga lebih memanfaatkan kehadiran teknologi berupa media sosial. Dari sini dapat diketahui bahwa pandemi mengharuskan seluruh lapisan masyarakat untuk terampil menggunakan teknologi dan beradaptasi dengan keadaan. Hal ini sejalan dengan penelitian yang dilakukan oleh Komalasari (2020), yang mengutarakan bahwa pemanfaatan media sosial di saat pandemi sangat penting, untuk meneruskan kegiatan yang tidak dapat dilakukan secara tatap muka. Hasil yang diperoleh dari penelitian tersebut adalah masyarakat memanfaatkan teknologi informasi dan komunikasi untuk kegiatan Work From Home, School From Home dan kepentingan informasi medis.

\section{Simpulan}

Penelitian ini menggambarkan bahwa covid-19 cukup berdampak pada psikologis individu dalam hal perubahan emosi, rasa cemas, dan takut. Tak hanya mempengaruhi psikologis, pandemi ini juga mengubah cara individu dalam menjalin hubungan sosial dengan masyarakat. Adanya protokol pencegahan covid mengharuskan individu antar satu sama lain berjaga jarak dan terdapat pembatasan interaksi secara langsung membuat individu berkomunikasi dengan perantara media online. Aktivitas sehari-hari pun mengalami perubahan yang cukup berbeda akibat adanya peraturan pencegahan covid. Namun pada kenyataannya di wilayah subjek bertempat tinggal masih banyak warganya yang tidak patuh pada protokol kesehatan berbeda dengan subjek yang memiliki pemahaman yang baik akan pencegahan pandemi tersebut.

Penelitian pada sebuah keluarga ini bersifat kontekstual dan memberikan gambaran bahwa jika sebuah keluarga sadar akan keberadaan covid-19, maka upaya pencegahan dilakukan mulai dari unit sosial terkecil ini. Keluarga yang dipilih sebagai objek penelitian menunjukkan bahwa dukungan anggota keluarga juga menjadi kunci penting terbangunnya kesadaran serta kekuatan untuk menghadapi pandemi. 


\section{Oetoesan Hindia: Telaah Pemikiran Kebangsaan}

Volume 2 No 2 Tahun $2020 \mathrm{Hlmn}$. 76-83

\section{Daftar Pustaka}

Komalasari, R. (2020). Manfaat Teknologi Informasi dan Komunikasi di Masa Pandemi Covid 19. TEMATIK, 7(1), 38-50.

Mundakir. (2007). Studi Fenomenologi Dampak Psikososial Keluarga akibat Lumpur Lapindo. Tesis tidak dipublikasikan. Universitas Indonesia.

World Health Organization. (2020). Worldometer Corona Virus Update (Live). Available online from: https://www.worldometers.info/ coronavirus/WHO. [Accessed August 11, 2020].

Zulva, T. N. I. (2020). Covid-19 Dan Kecenderungan Psikosomatis. J. Chem. Inf. Model, 1-4. 